\title{
BADANIE PARCIA NA PRZYCZÓŁEK MOSTOWY ZASYPKI Z MATERIAŁÓW Z RECYKLINGU OPON SAMOCHODOWYCH*
}

\author{
Aleksander Duda ${ }^{凶}$, Tomasz Siwowski \\ Wydział Budownictwa, Inżynierii Środowiska i Architektury, Politechnika Rzeszowska, Rzeszów
}

\begin{abstract}
STRESZCZENIE
W artykule opisano badania polowe rozkładu parcia zasypki na przyczółek obiektu mostowego. Zasypkę przyczółka stanowi materiał z recyklingu zużytych opon (sprasowanych w pakiety) z przewarstwieniami z piasku średniego oraz warstwa buforowa ze strzępów gumowych. Rozkład parcia zasypki mierzono za pomocą czujników parcia w sposób ciągły przez okres 3 miesięcy. W czasie badań zrealizowano statyczne i dynamiczne obciążenie przyczółka oraz symulację termicznego wydłużenia/skrócenia przęsła mostu zintegrowanego z przyczółkiem przez cykliczne przemieszczenia korpusu. Wyniki badań porównano z wynikami analizy numerycznej zadania. Zgodność wyników badań oraz analiz numerycznych była duża, a maksymalna różnica wyniosła około $25 \%$. Jednocześnie, zarówno na podstawie badań, jak i analiz, stwierdzono 2- do 4-krotną redukcję parcia na przyczółek w przypadku zastosowania zasypki z pakietów gumowych w porównaniu do zasypki konwencjonalnej z piasku średniego.
\end{abstract}

Słowa kluczowe: przyczółek mostowy, parcie zasypki, pakiety z opon, recykling

\section{WSTĘP}

Zużyte opony samochodowe są odpadem niezwykle trwałym, który nie ulega naturalnemu rozkładowi i wykazuje odporność na działanie wody, różnego rodzaju chemikaliów oraz ekstremalnych wartości temperatury. Obecnie w Polsce zagospodarowanie zużytych opon samochodowych polega na recyklingu materiałowym (wysokoenergetyczna granulacja) oraz odzysku energii (spalanie opon w piecach cementowni). Brakuje rozwiązań proekologicznych, takich jak recykling produktowy, w którym wykorzystuje się ponownie odpady o niskim stopniu przetworzenia dla uzyskania produktów o nowych, pożądanych cechach. W przypadku zużytych opon recykling produktowy polega na rozdrabnianiu opon do frakcji strzępów

\footnotetext{
* Badania wykonano w ramach projektu współfinansowanego ze środków Europejskiego Funduszu Rozwoju Regionalnego pt. „ReUse - Innowacyjne materiały z recyklingu, zwiększające trwałość obiektów mostowych” (Innotech nr K3/ /IN3/38/228116/NCBiR/15).

Program MATLAB wykorzystany do przeprowadzenia badań został zakupiony w wyniku realizacji projektu UDA-RPPK.01.03.00-18-003/10-00 „Budowa, rozbudowa i modernizacja bazy naukowo-badawczej Politechniki Rzeszowskiej” współfinansowanego ze środków Unii Europejskiej w ramach Regionalnego Programu Operacyjnego Województwa Podkarpackiego na lata 2007-2013, Priorytet I. Konkurencyjna i Innowacyjna Gospodarka, Działanie 1.3 Regionalny system innowacji.
}

凶aduda@prz.edu.pl 
gumowych (wymiar 50-300 mm), wykorzystaniu całych opon lub ich prasowaniu do formy pakietów. Do wykorzystania $\mathrm{w}$ budownictwie, $\mathrm{w}$ tym szczególnie w budownictwie komunikacyjnym i hydrotechnicznym, najlepiej nadaje się materiał gumowy z recyklingu opon w formie pakietów (Duda, Sobala, Siwowski i Kaleta, 2016; Duda, 2017a).

W Zakładzie Dróg i Mostów Politechniki Rzeszowskiej prowadzi się badania laboratoryjne i polowe nad wykorzystaniem zużytych opon samochodowych sprasowanych do formy pakietów w budownictwie komunikacyjnym. W badaniach laboratoryjnych sprawdzono dotychczas:

- wytrzymałość na ścinanie geokompozytów złożonych z pakietów $\mathrm{z}$ opon $\mathrm{z}$ materiałami zasypowymi, takimi jak kruszywo gumowe, keramzyt i kruszywo naturalne (Duda, Sobala i Siwowski, 2017),

- sztywność pakietów z opon,

- nośność drutów spinających pakiety i ich połączeń (Duda, 2017b, c).

Badania polowe sa prowadzone na pełnowymiarowym modelu przyczółku mostowego oraz na odcinku dojazdu do mostu na nasypie. Zakres prowadzonych aktualnie badań polowych obejmuje (Duda i Sobala, 2017a, b):

- określenie wartości i rozkładu parcia na konstrukcje oporowe z geokompozytu złożonego z pakietów i materiału zasypowego w warunkach obciążenia zasypką oraz obciążenia statycznego i dynamicznego naziomu,

- badania tłumienia drgań przez nasypy zbudowane z pakietów z opon,

- ocenę deformacji strefy dojazdu do przyczółka mostowego, którego zasypka została wykonana z pakietów i materiału zasypowego,

- badania środowiskowe pakietów z opon.

$\mathrm{W}$ artykule opisano badania rozkładu sił parcia na przyczółek mostowy z zasypką w postaci pakietów $\mathrm{z}$ opon $\mathrm{z}$ przewarstwieniami $\mathrm{z}$ piasku średniego i warstwą buforową ze strzępów gumowych, ułożoną między korpusem a pakietami. Wyniki pomiarów terenowych porównano $\mathrm{z}$ wynikami symulacji rozkładu parcia, otrzymanymi $z$ analizy numerycznej przeprowadzonej w programie GEO5 metodą elementów skończonych (MES).

\section{PAKIETY SPRASOWANYCH ZUŻYTYCH OPON SAMOCHODOWYCH (SZOS)}

Pakiety sprasowanych zużytych opon samochodowych (dalej: pakiety SZOS) to nowy materiał budowlany $\mathrm{z}$ recyklingu produktowego. Prasowanie i pakowanie sprasowanych opon było odpowiedzią na konieczność ograniczenia wielkości składowisk opon oraz na zwiększające się stale ryzyko samozapłonu opon na składowiskach. Zużyte opony są ściskane w prasie (jednocześnie ok. 100-135 opon) i spinane taśmami z tworzyw sztucznych lub ocynkowanymi drutami wysokiej wytrzymałości ze stali sprężynowej. Gotowy pakiet $\mathrm{z}$ opon przypomina prostopadłościan (rys. 1), którego wysokość zależy od średnicy sprasowanych opon, szerokość od wymiaru prasy, a długość od liczby wykorzystanych opon (Duda i Sobala, 2017a, b). Wykorzystanie pakietów SZOS
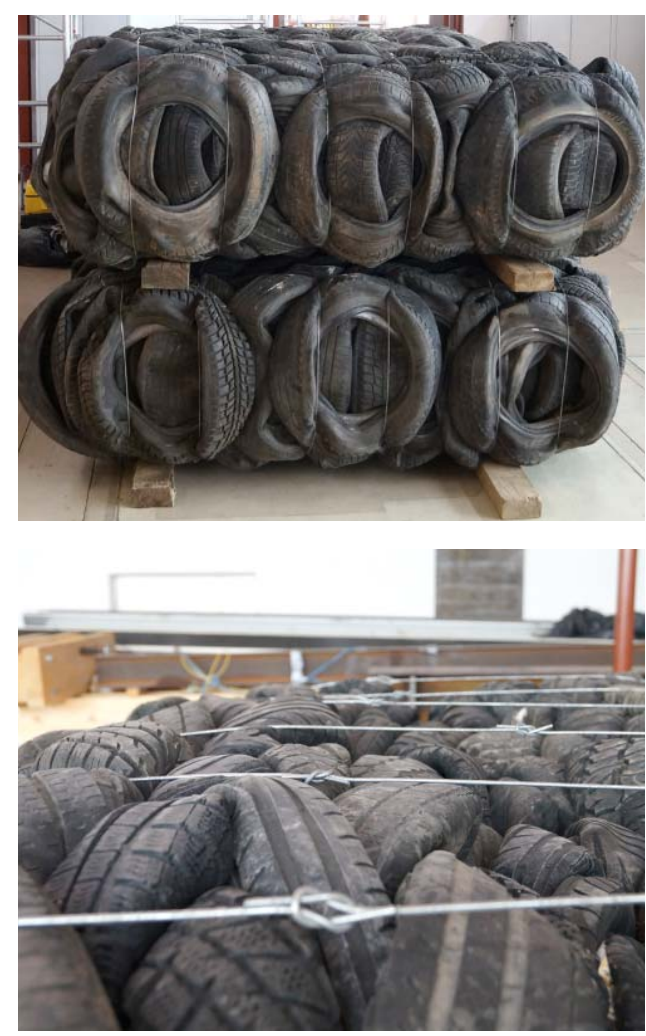

Rys. 1. Pakiety SZOS (u góry), połączenie drutów spinających pakiety (na dole)

Fig. 1. Tyre bales (top) and wires connection spanning the tyre bales (down) 
Tabela 1. Porównanie właściwości pakietów SZOS z kruszywami naturalnymi

Table 1. Comparison of the tyre bales properties and natural aggregates

\begin{tabular}{lccc}
\hline $\begin{array}{l}\text { Cecha } \\
\text { Feature }\end{array}$ & $\begin{array}{c}\text { Pakiety SZOS } \\
\text { Tyre bales }\end{array}$ & $\begin{array}{c}\text { Kruszywo mineralne (piaski, żwiry) } \\
\text { Minerals (sand, gravel) }\end{array}$ & $\begin{array}{c}\text { Źródło } \\
\text { Source }\end{array}$ \\
\hline $\begin{array}{l}\text { Ciężar objętościowy }\left[\mathrm{kN} \cdot \mathrm{m}^{-3}\right] \\
\text { Unit weight }\end{array}$ & $5-6$ & $18-20$ & (PAS-108, 2007) \\
\hline $\begin{array}{l}\left.\text { Kąt poślizgu }{ }^{\circ}\right]^{\mathrm{a}} \\
\text { Friction angle }\end{array}$ & $35-36$ & $35-40$ & $\begin{array}{c}\text { (Zornberg, Christopher } \\
\text { i Oosterbaan, 2005) }\end{array}$ \\
\hline $\begin{array}{l}\left.\text { Kąt tarcia wewnętrznego }{ }^{\circ}\right] \\
\text { Friction angle }\end{array}$ & - & $40-100$ & (PN-B-03020, 1981) \\
\hline $\begin{array}{l}\text { Moduł odkształcenia }[\mathrm{MPa}] \\
\text { Elastic modulus }\end{array}$ & $0,8-1,3$ & (PAS-108, 2007) \\
\hline $\begin{array}{l}\text { Współczynnik filtracji }\left[\mathrm{cm}^{\circ} \cdot \mathrm{s}^{-1}\right] \\
\text { Permeability coefficient }\end{array}$ & $2-4$ & $0,1-1$ & (PAS-108, 2007) \\
\hline $\begin{array}{l}\text { Przewodność cieplna }\left[\mathrm{W} \cdot \mathrm{m}^{-1} \cdot \mathrm{K}^{-1}\right] \\
\text { Thermal conductivity }\end{array}$ & 0,07 & $0,4-0,7$ & (Zornberg i in., 2005) \\
\hline
\end{tabular}

${ }^{a}$ Wartość odnosi się do poślizgu między pakietami bez warstwy zasypki / Value refers to the friction between tyre bales without backfill.

jest już dość powszechne w krajach wysokorozwiniętych, a w Wielkiej Brytanii opracowano szczegółową specyfikację, opisującą sposób produkcji i wymiary pakietów (PAS-108, 2007).

W tabeli 1 zestawiono podstawowe właściwości pakietów z opon, które w większości są korzystniejsze niż analogiczne właściwości kruszyw naturalnych. Jedyną wadą pakietów jest ich duża ściśliwość wynikająca z niskich wartości modułu odkształcenia postaciowego gumy. W nasypach komunikacyjnych problem ten można jednak rozwiązać, stosując warstwy transmisyjne z kruszywa naturalnego o odpowiedniej grubości, układane na warstwie pakietów. Warstwa transmisyjna pozwala na ograniczenie odkształceń nawierzchni od obciążeń użytkowych, wynikających z odkształcalności pakietów opon, do akceptowanego poziomu.

\section{STANOWISKO BADAWCZE}

Badania polowe przyczółku mostowego z zasypką z pakietów SZOS wykonano na specjalnym stanowisku badawczym, symulującym rzeczywistą pracę przyczółka oraz odcinak dojazdu. W skład stanowiska wchodzą komora badawcza (rys. 3, rys. 4) i odcinek dojazdowy (rys. 2, rys. 4).

Komorę badawczą wykonano z grodzic stalowych GU16N długości 8-10 m pogrążonych po obwodzie i zwieńczonych żelbetowym oczepem. Komora ma wymiary w planie po obrysie zewnętrznym $6,1 \times 7,75 \mathrm{~m}$ i składa się z dwóch części: badawczej i pomiarowej, przedzielonych ruchomą ścianą pomiarową. Komora pomiarowa o wymiarach $1,5 \times 5,0 \mathrm{~m}$ przeznaczona jest do montażu instrumentów pomiarowych (czujniki sił, czujnik przemieszczeń, siłowniki), ich okablowania oraz inspekcji stanowiska. Część badawcza o wymiarach 5,0 $\times 5,0 \mathrm{~m}$ jest przeznaczona do wykonania różnych wariantów zasypek przyczółka. Głębokość komory wynosi 6,0 i 5,38 m odpowiednio w częściach pomiarowej i badawczej. Ściana pomiarowa jest podzielona na trzy panele, $\mathrm{z}$ których środkowy jest panelem pomiarowym, na którym zamontowane są czujniki sił parcia. Każdy panel ma wysokość $5,75 \mathrm{~m}$, szerokość $1,66 \mathrm{~m}$ i składa się z żelbetowej płyty o grubości $0,15 \mathrm{~m}$ i długości $5,0 \mathrm{~m}$, zespolonej $\mathrm{z}$ dwoma kształtownikami stalowymi HEB 340 w rozstawie $1,35 \mathrm{~m}$. Kształtowniki przytwierdzone są do płyty dennej przegubowo za pomocą połączenia sworzniowego. 


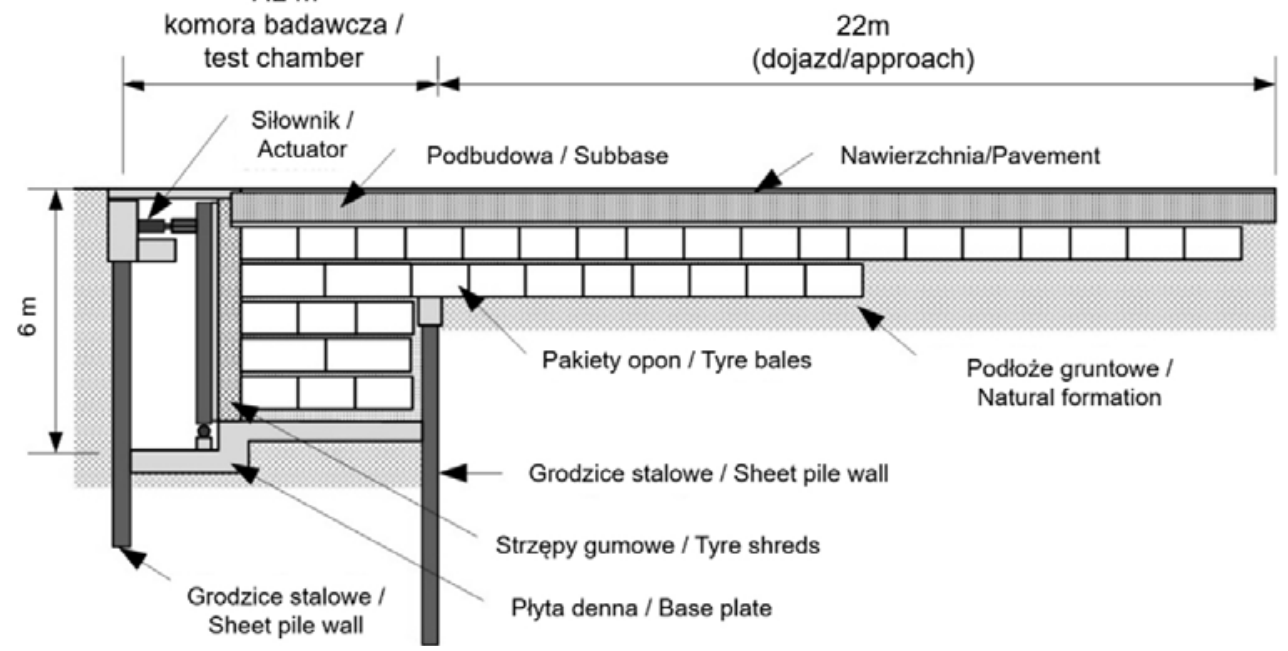

Rys. 2. Schemat stanowiska badawczego z odcinkiem dojazdu

Fig. 2. Scheme of the test stand with road approach section
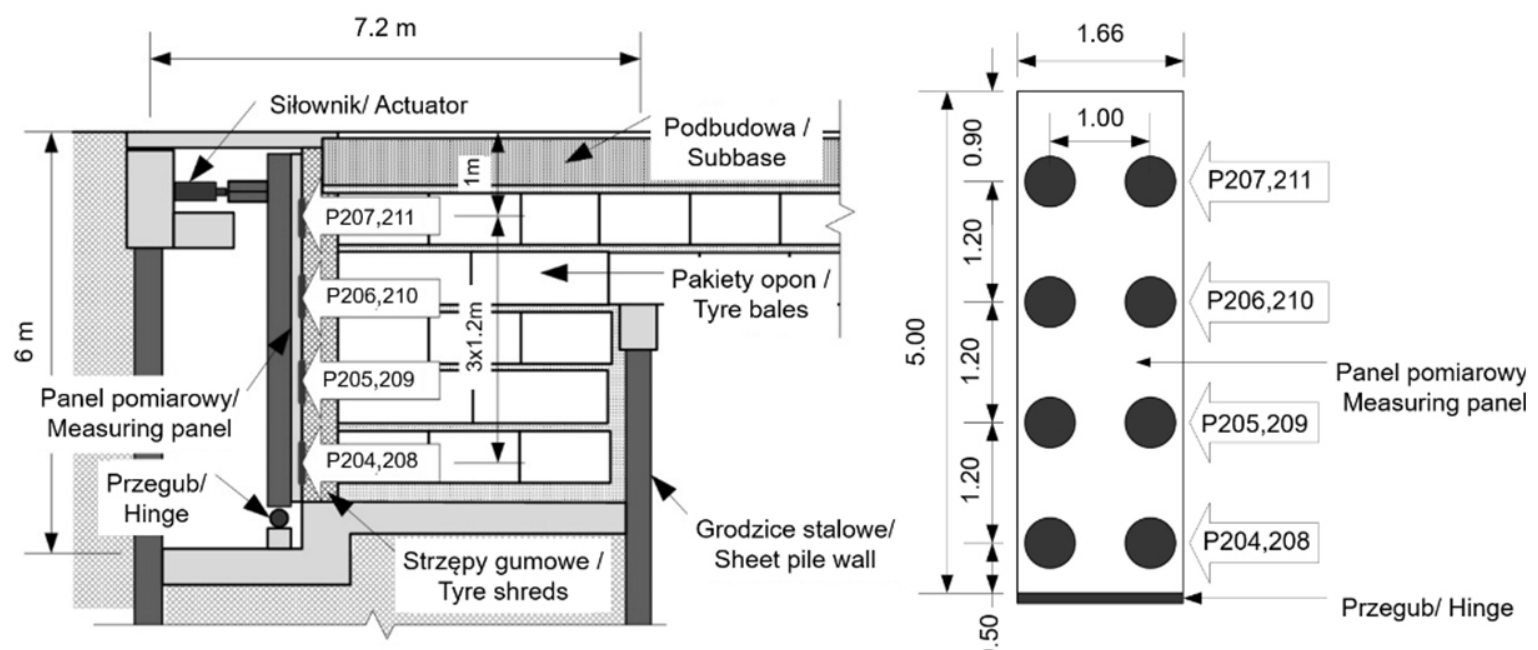

Rys. 3. Rozmieszczenie czujników sił parcia w komorze badawczej (z lewej), rozmieszczenie czujników sił parcia na panelu pomiarowym (z prawej)

Fig. 3. Arrangement of pressure sensors in test chamber (left), arrangement of pressure sensors on measuring panel (right)
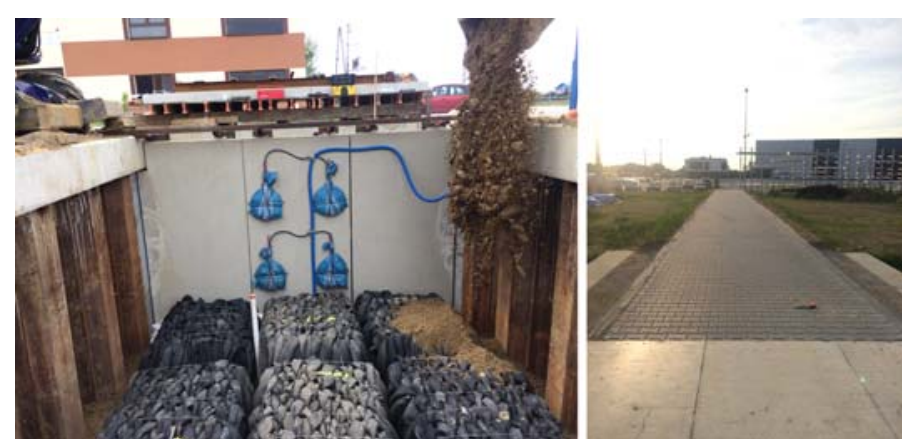

Rys. 4. Czujniki sił parcia zainstalowane na ścianie pomiarowej podczas wykonywania zasypki (z lewej), odcinek dojazdowy (z prawej)

Fig. 4. Pressure sensors installed on the measuring wall during performing backfill (left), all approach section (right) 
Badawczy odcinek dojazdowy ma jezdnię $\mathrm{z}$ jednym pasem ruchu o szerokości $3 \mathrm{~m}$. Długość dojazdu wynosi $22 \mathrm{~m}$. W jego skład wchodzą trzy odcinki:

- odcinek $1 \mathrm{z}$ wbudowanymi dwoma warstwami pakietów o długości $10 \mathrm{~m}$,

- odcinek $2 \mathrm{z}$ wbudowaną jedną warstwą pakietów o długości $8 \mathrm{~m}$,

- odcinek 3 referencyjny bez pakietów o długości $4 \mathrm{~m}$. Nad warstwą pakietów ułożono warstwę transmisyjną z kruszywa naturalnego o grubości $0,70 \mathrm{~m}$, podsypkę cementowo-piaskową o grubości $0,10 \mathrm{~m}$ oraz nawierzchnię z kostki betonowej o grubości $0,08 \mathrm{~m}$.

\section{PROGRAM I PRZEBIEG BADAŃ}

\section{Program badań}

Zaplanowano badanie parcia zasypki dla zaprojektowanego schematu wypełnienia komory badawczej: zasypka z pakietów SZOS w zasypce z piasku średniego oraz warstwa buforowa ze strzępów gumowych.

Badania obejmowały pięć etapów:

I. Badania pod obciążeniem statycznym i dynamicznym (obciążenie płytami drogowymi, pojazdem o masie $32 \cdot 10^{3} \mathrm{~kg}$ ).

II. Cykliczne wymuszenia przemieszczeń górnej części ściany pomiarowej o wartość $\pm 15 \mathrm{~mm}$ (867 cykli).
III. Cykliczne wymuszenia przemieszczeń górnej części ściany pomiarowej o wartość $\pm 30 \mathrm{~mm}$ (1309 cykli).

IV. Cykliczne wymuszenia przemieszczeń górnej części ściany pomiarowej o wartość $\pm 45 \mathrm{~mm}$ (575 cykli).

V. Ponowne badania pod obciążeniem statycznym i dynamicznym (obciążenie płytami drogowymi, pojazdem o masie $32 \cdot 10^{3} \mathrm{~kg}$ ).

Rozkład parcia w etapach I i V symuluje pracę przyczółków tradycyjnych, wspornikowych, a w etapach II-IV przyczółków zintegrowanych z przęsłem (wpływy termiczne). Liczbę cykli pracy siłowników wymuszających przemieszczenia ściany pomiarowej $\mathrm{w}$ etapach II, III i IV określono jako wartość średnią dla reprezentatywnych dla obszaru Polski wydłużeń/skróceń termicznych w okresie 30 lat (projektowana trwałość nawierzchni drogowej) dla typowego obiektu mostowego o długości całkowitej 120 m (rys. 5). Liczby cykli oraz wartości przemieszczeń przyjęto na podstawie pomiarów temperaturowych w latach 1970-2000 (Sobala, 2002) oraz zaleceń normy PN-EN 1991-1-5:2010.

\section{Przebieg badań}

Cykliczne wymuszenia przemieszczenia ściany pomiarowej w etapach II, III i IV realizowano $\mathrm{z}$ wykorzystaniem prasy hydraulicznej, sterowanej przez

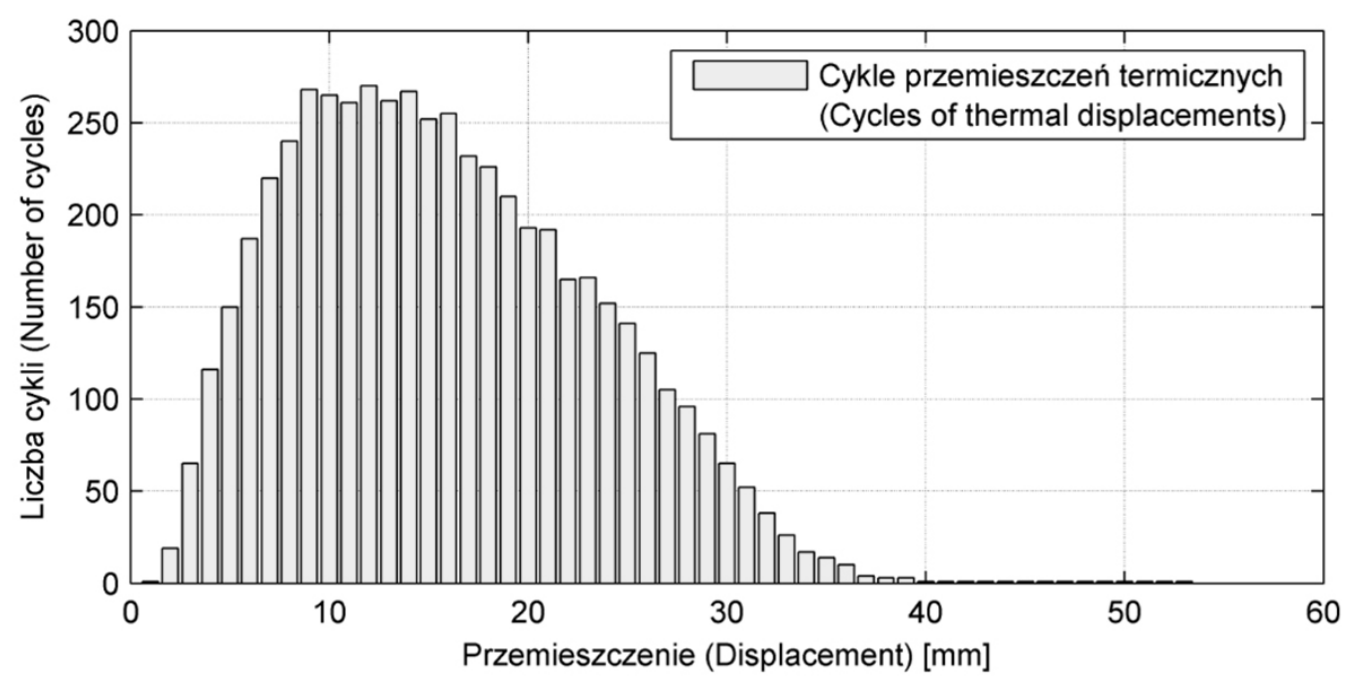

Rys. 5. Cykle przemieszczeń termicznych dla przęsła mostu zespolonego o długości $120 \mathrm{~m}$ (Sobala, 2002)

Fig. 5. Cycles of thermal displacements for the composite $120 \mathrm{~m}$ long bridge (Sobala, 2002) 
operatora $\mathrm{z}$ prędkością $0,5-1,0 \mathrm{~mm} \cdot \mathrm{min}^{-1}$. Podczas badań wykonywano pomiary:

- parcia zasypki na ścianę pomiarową (8 czujników),

- siły wymuszającej zadane przemieszczenie ściany (2 czujniki),

- temperatury w zasypce (10 czujników),

- wychylenia poziomego ściany (2 czujniki),

- deformacji konstrukcji nawierzchni (za pomocą niwelacji geodezyjnej).

Rejestracja pomiarów sił parcia, siły generowanych przez siłowniki i temperatury odbywała się automatycznie co $3 \mathrm{~min}$. Dane pomiarowe były zbierane za pomoca systemu akwizycji OMNIA CAB2. Rejestracja wychyleń poziomych ściany odbywała się automatycznie z częstotliwością $10 \mathrm{~Hz}$. Dane pomiarowe były zbierane za pomoca systemu akwizycji HBM typu Spider. Dokładność pomiarów deformacji za pomocą niwelacji geodezyjnej wynosiła $\pm 0,25 \mathrm{~mm}$.

\section{MODEL NUMERYCZNY}

\section{Model stanowiska badawczego}

Model numeryczny stanowiska badawczego wykonano w programie GEO5 w module MES, w płaszczyźnie 2D. Zamodelowano obszar roboczy o wymiarach $42,5 \times 20 \mathrm{~m}$, za pomocą siatki elementów skończo- nych trójkątnych i czworokątnych o wymiarze $0,4 \mathrm{~m}$ (rys. 6). W modelu odwzorowano: grunty zalegające w podłożu, betonową płytę denną stanowiska badawczego, ścianę pomiarową, ściany komory badawczej $\mathrm{z}$ grodzic stalowych, układ warstw materiałów w komorze badawczej i na odcinku dojazdu. Ścianę pomiarową oraz ściany komory $\mathrm{z}$ grodzic zamodelowano elementami belkowymi.

Modelując obciążenie stanowiska, uwzględniono rzeczywiste fazy wykonania stanowiska badawczego (wykop, budowa), fazy wypełniania komory badawczej zasypka oraz wymuszane poziome przemieszczenia górnej części ściany pomiarowej o wartościach 15 , 30 i $45 \mathrm{~mm}$ (etapy II-IV).

\section{Modele materiałowe podłoża i pakietów SZOS}

$\mathrm{W}$ modelu numerycznym przyjęto dwa modele materiałowe relacji naprężenie - odkształcenie:

- model sprężysty (zgodnie z prawem Hooke'a) dla: warstwy buforowej ze strzępów gumowych, betonowej płyty fundamentowej oraz pakietów SZOS,

- model Coulomba-Mohra dla: gruntów w podłożu, podbudowy z kruszywa oraz zasypki z piasku średniego.

W tabelach 2 i 3 podano charakterystyki materiałowe przyjęte $w$ analizie numerycznej.

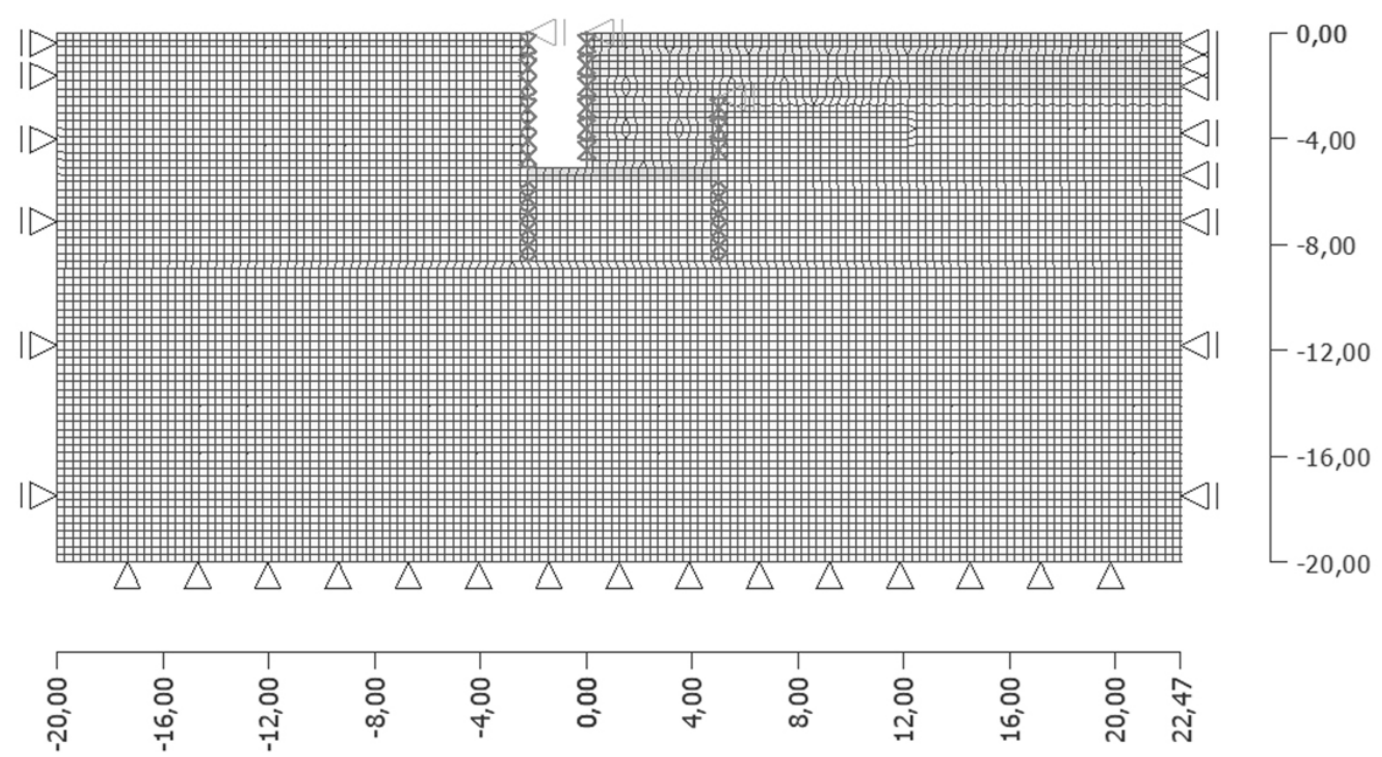

Rys. 6. Wymiary obszaru roboczego wraz z siatką elementów skończonych i układem zamodelowanych warstw

Fig. 6. Dimensions area of the model with finite elements mesh and an arrangement of modeled layers 
Tabela 2. Charakterystyki materiałowe dla modelu sprężystego

Table 2. Materials characteristics for elastic model

\begin{tabular}{lcccc}
\hline $\begin{array}{l}\text { Materiał } \\
\text { Material }\end{array}$ & $\begin{array}{c}\text { Moduł odkształcenia } \\
\text { Elastic modulus [MPa] }\end{array}$ & $\begin{array}{c}\text { Liczba Poissona } \\
\text { Poisson's number [-] }\end{array}$ & $\begin{array}{c}\text { Ciężar objętościowy } \\
\text { Unit weight }\left[\mathrm{kN} \cdot \mathrm{m}^{-3}\right]\end{array}$ & $\begin{array}{c}\text { Źródło } \\
\text { Source }\end{array}$ \\
\hline $\begin{array}{l}\text { Płyta denna } \\
\text { Base plate }\end{array}$ & 32000 & 0,2 & 25 & (PN-EN 1992-1-1: 2008) \\
\hline $\begin{array}{l}\text { Strzępy z opon } \\
\text { Tyre shreds }\end{array}$ & 0,8 & 0,25 & 5,0 & (Geosyntec Consultants, 2008) \\
\hline $\begin{array}{l}\text { Pakiety SZOS } \\
\text { Tyre bales }\end{array}$ & 12,75 & 0,1 & 7,0 & $\begin{array}{c}\text { (Duda i Sobala, 2017a, b; } \\
\text { Zornberg i in., 2005) }\end{array}$ \\
\hline
\end{tabular}

${ }^{a}$ Wartość ciężaru objętościowego oraz modułu odkształcenia uśredniono, przyjmując wysokość pakietu SZOS równą $0,8 \mathrm{~m}(0,68 \mathrm{~m}$ - pakiet SZOS + 0,12 m - piasek średni) - Value of unit weight and elastic modulus averaged taking the height of tyre bales equal to $0.8 \mathrm{~m}(0.68 \mathrm{~m}-$ tyre bale $+0.12 \mathrm{~m}-$ medium sand $)$.

Tabela 3. Charakterystyki materiałowe dla gruntów

Table 3. Materials characteristics for soils

\begin{tabular}{|c|c|c|c|c|c|}
\hline $\begin{array}{l}\text { Materiał } \\
\text { Material }\end{array}$ & $\begin{array}{c}\text { Moduł } \\
\text { odkształcenia } \\
\text { Elastic modulus } \\
{[\mathrm{MPa}]}\end{array}$ & $\begin{array}{c}\text { Liczba } \\
\text { Poissona } \\
\text { Poisson's } \\
\text { number [-] }\end{array}$ & $\begin{array}{c}\text { Ciężar } \\
\text { objętościowy } \\
\text { Unit weight } \\
{\left[\mathrm{kN} \cdot \mathrm{m}^{-3}\right]}\end{array}$ & $\begin{array}{c}\text { Kąt tarcia } \\
\text { wewnętrznego } \\
\text { Friction angle } \\
\gamma\left[{ }^{\circ}\right]\end{array}$ & $\begin{array}{c}\text { Spójność } \\
\text { Cohesion } \\
{[\mathrm{kPa}]}\end{array}$ \\
\hline $\begin{array}{l}\text { Grunt rodzimy } 1 \text { piasek drobny }{ }^{\mathrm{a}} \\
\text { Ground } 1 \text { - fine sand }\end{array}$ & 50 & 0,3 & 19 & 30 & 0 \\
\hline $\begin{array}{l}\text { Grunt rodzimy } 2 \text { piasek gliniasty } \\
\text { Ground } 2 \text { - silty sand }\end{array}$ & 30 & 0,3 & 19 & 22 & 10 \\
\hline $\begin{array}{l}\text { Podbudowa/zasypka - piasek średni }{ }^{\text {b }} \\
\text { Subbase/backfill - medium sand }\end{array}$ & 80 & 0,25 & 18,5 & 35 & 0 \\
\hline
\end{tabular}

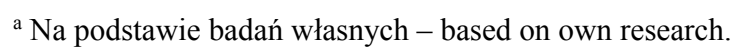

${ }^{\mathrm{b}}$ Na podstawie PN-B-03020:1981 - based on PN-B-03020:1981.

\section{WYNIKI I DYSKUSJA}

W celach porównawczych na rysunkach $7-14$ przedstawiono wyniki pomiarów terenowych z czujników parcia (P204-P211) wraz z wynikami analizy numerycznej dla dwóch materiałów zasypki: zasypki z pakietów SZOS - dla przemieszczeń ściany w zakresie $0-45 \mathrm{~mm}$, oraz zasypki konwencjonalnej z piasku średniego - dla przemieszczeń ściany w zakresie $0-15 \mathrm{~mm}$. Na rysunku 15 przedstawiono wynik pomiarów geodezyjnych mierzonych wzdłuż osi podłużnej stanowiska badawczego.

Analiza wykresów (rys. 7-14) pozwala oszacować rozbieżność wyników z modelu numerycznego z wynikami badań terenowych na poziomie $25 \%$ (wartość uśredniona dla 8 czujników parcia), przy czym prawie zawsze pomierzone wartości parcia są mniejsze niż otrzymane z modelu numerycznego. Różnice między wynikami badań i analizy numerycznej wynikają z:

- przyjęcia w modelu numerycznym większej sztywności materiałów gumowych (szczególnie warstwy buforowej ze strzępów) niż uzyskana w warunkach rzeczywistych i ustalona na podstawie badań,

- wpływu temperatury na rozkład parcia (badania realizowane w miesiącach letnich). 


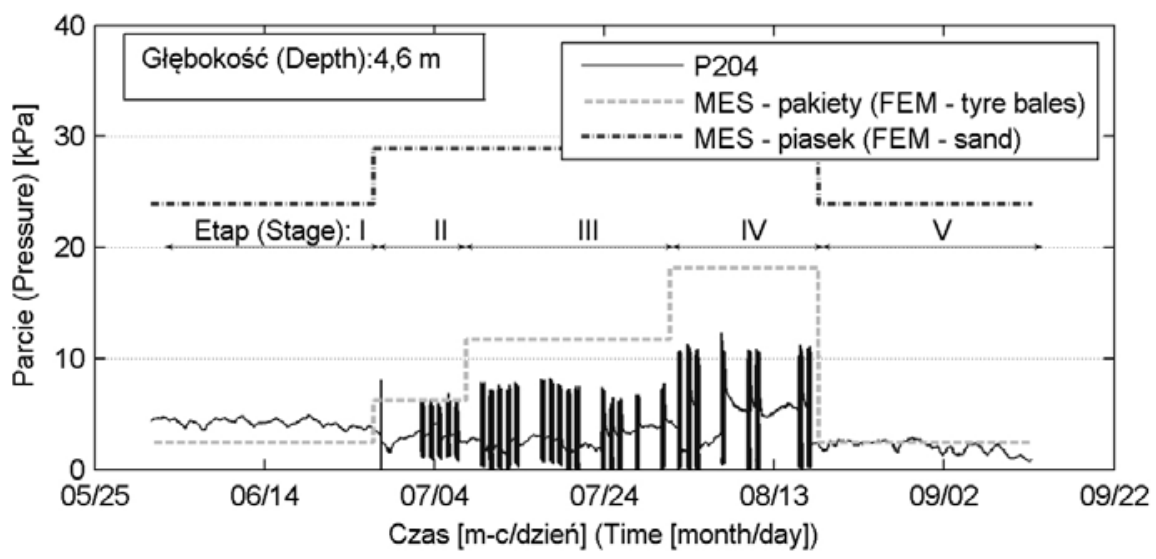

Rys. 7. Rozkład sił parcia dla czujnika P204 z pomiarów oraz analizy MES

Fig. 7. Pressure distribution for sensor P204 with measurement and FEM

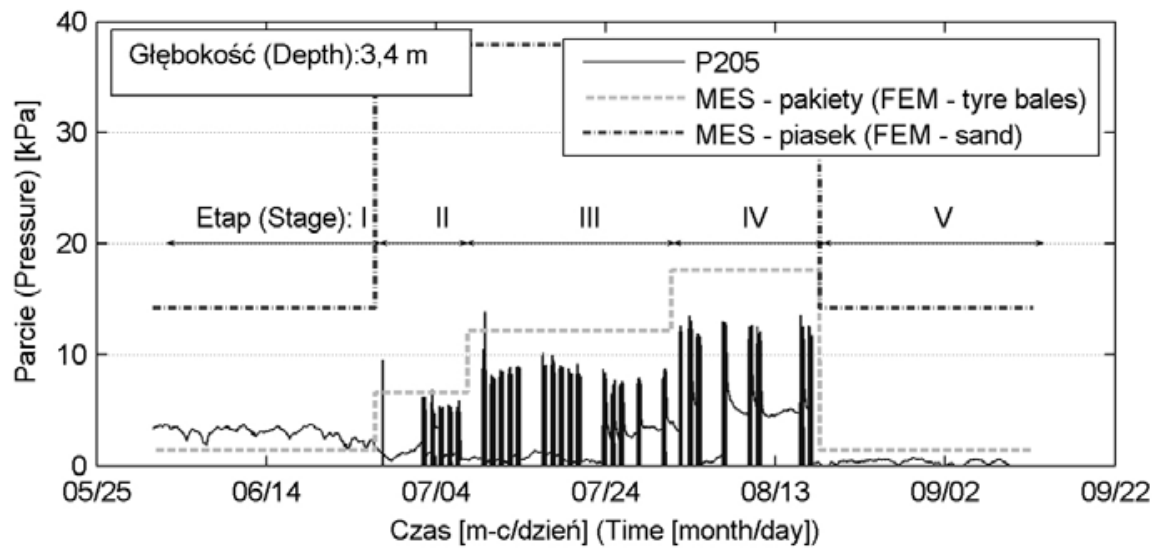

Rys. 8. Rozkład sił parcia dla czujnika P205 z pomiarów oraz analizy MES

Fig. 8. Pressure distribution for sensor P205 with measurement and FEM

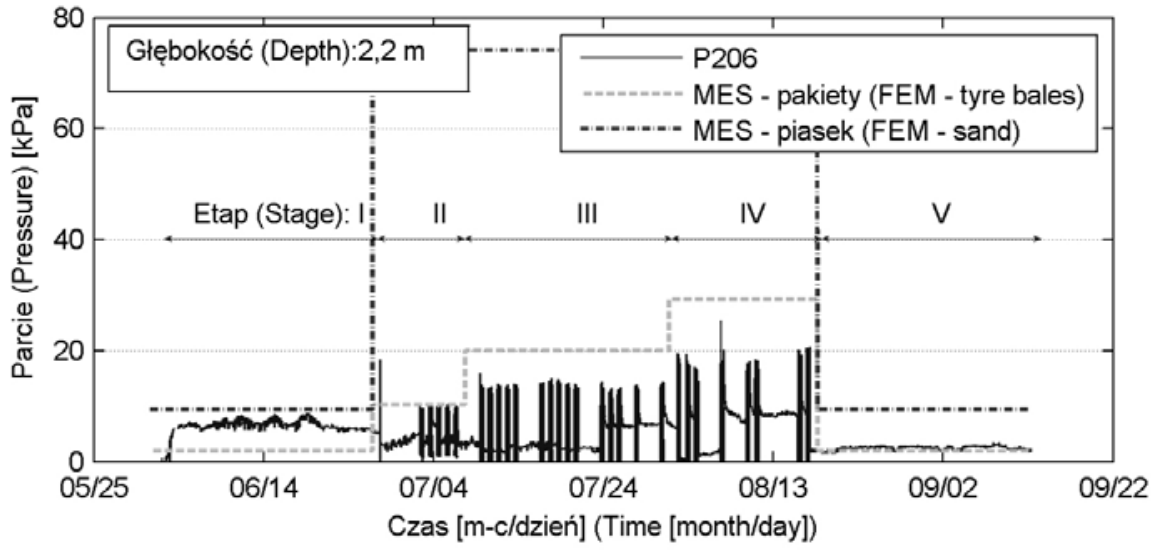

Rys. 9. Rozkład sił parcia dla czujnika P206 z pomiarów oraz analizy MES

Fig. 9. Pressure distribution for sensor P206 with measurement and FEM 


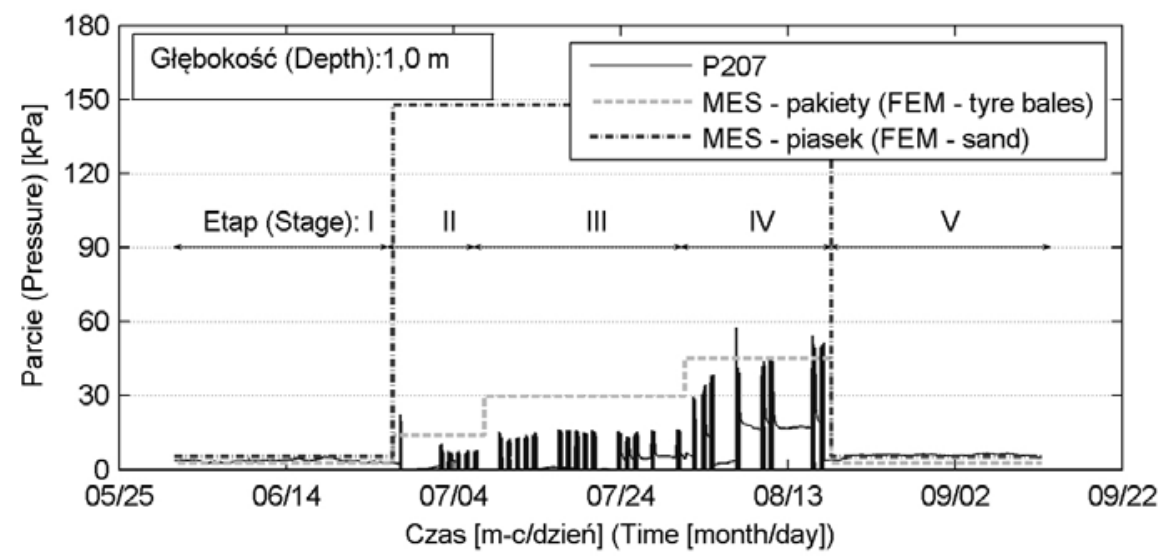

Rys. 10. Rozkład sił parcia dla czujnika $\mathrm{P} 207$ z pomiarów oraz analizy MES

Fig. 10. Pressure distribution for sensor P207 with measurement and FEM

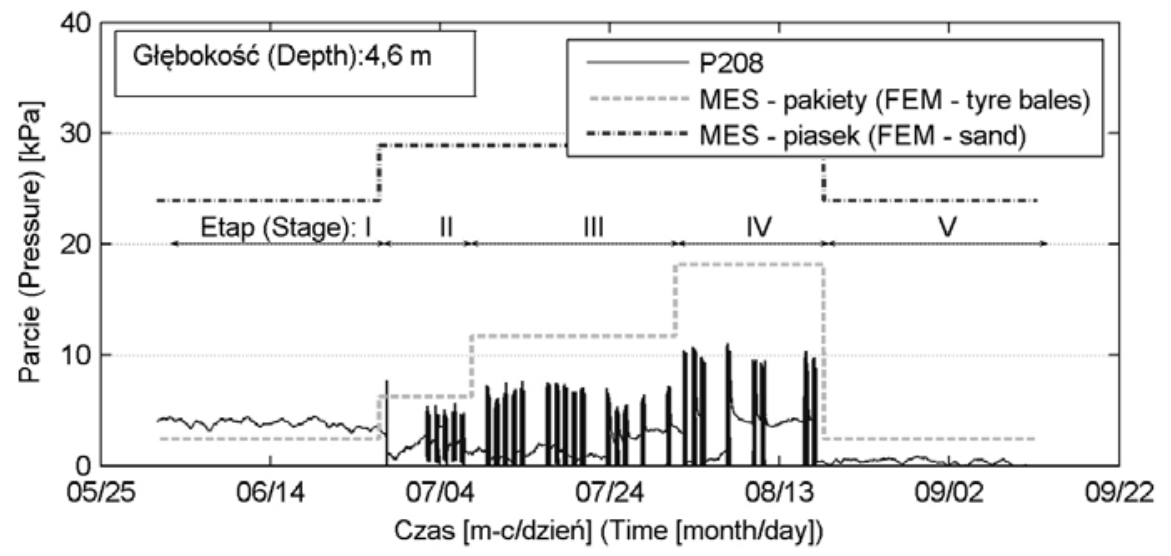

Rys. 11. Rozkład sił parcia dla czujnika P208 z pomiarów oraz analizy MES

Fig. 11. Pressure distribution for sensor P208 with measurement and FEM

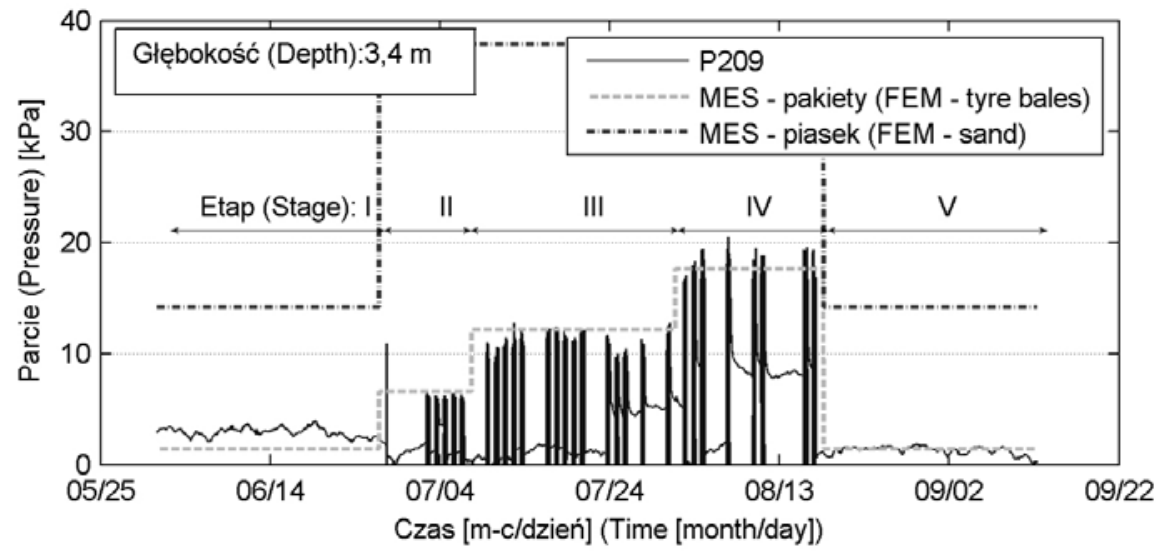

Rys. 12. Rozkład sił parcia dla czujnika P209 z pomiarów oraz analizy MES

Fig. 12. Pressure distribution for sensor $\mathrm{P} 209$ with measurement and FEM 


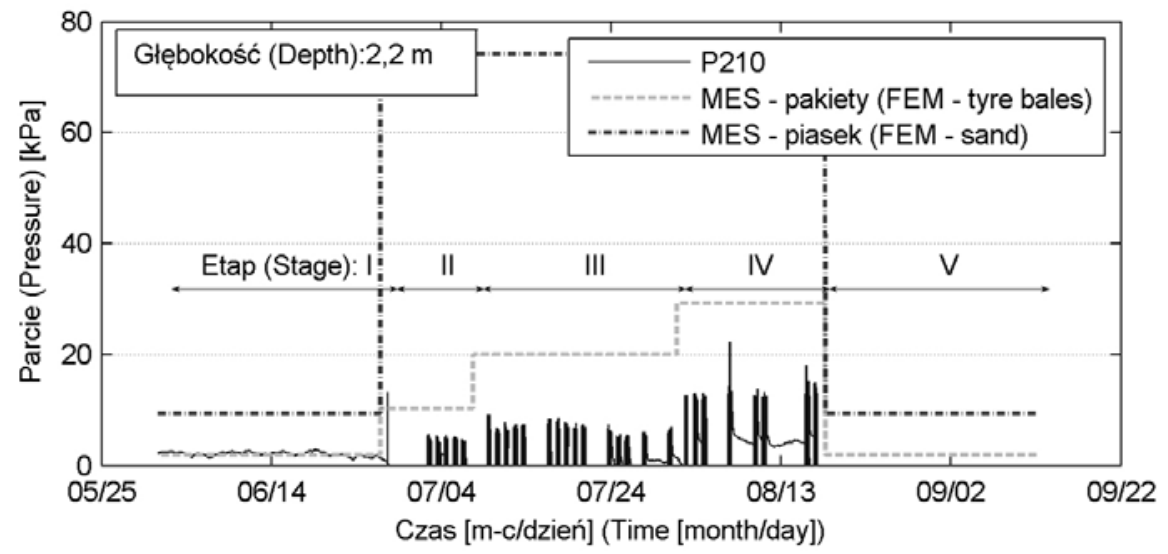

Rys. 13. Rozkład sił parcia dla czujnika $\mathrm{P} 210 \mathrm{z}$ pomiarów oraz analizy MES

Fig. 13. Pressure distribution for sensor $\mathrm{P} 210$ with measurement and FEM

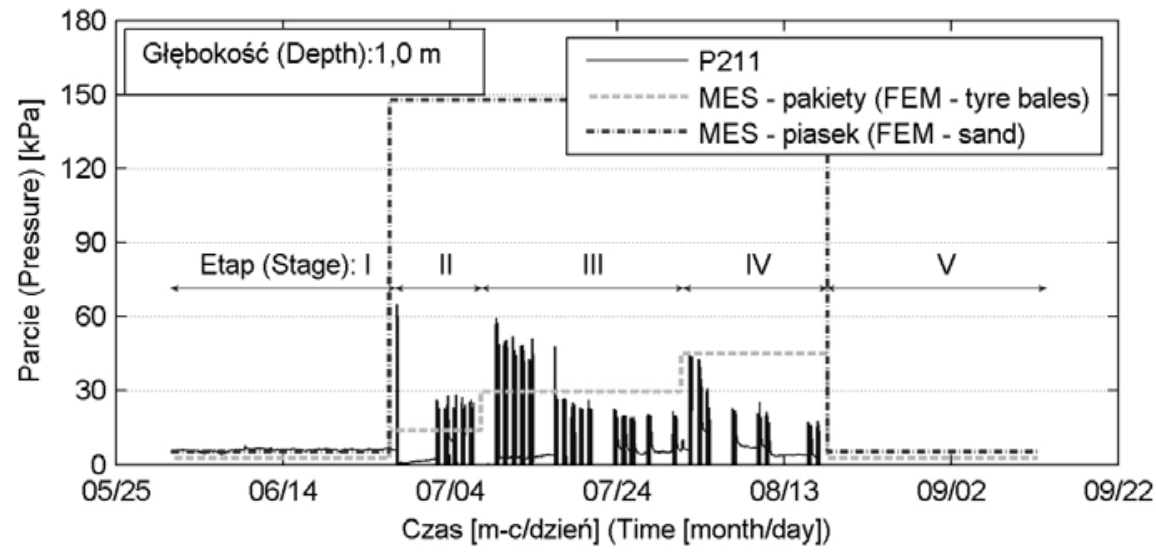

Rys. 14. Rozkład sił parcia dla czujnika P211 z pomiarów oraz analizy MES

Fig. 14. Pressure distribution for sensor P211 with measurement and FEM

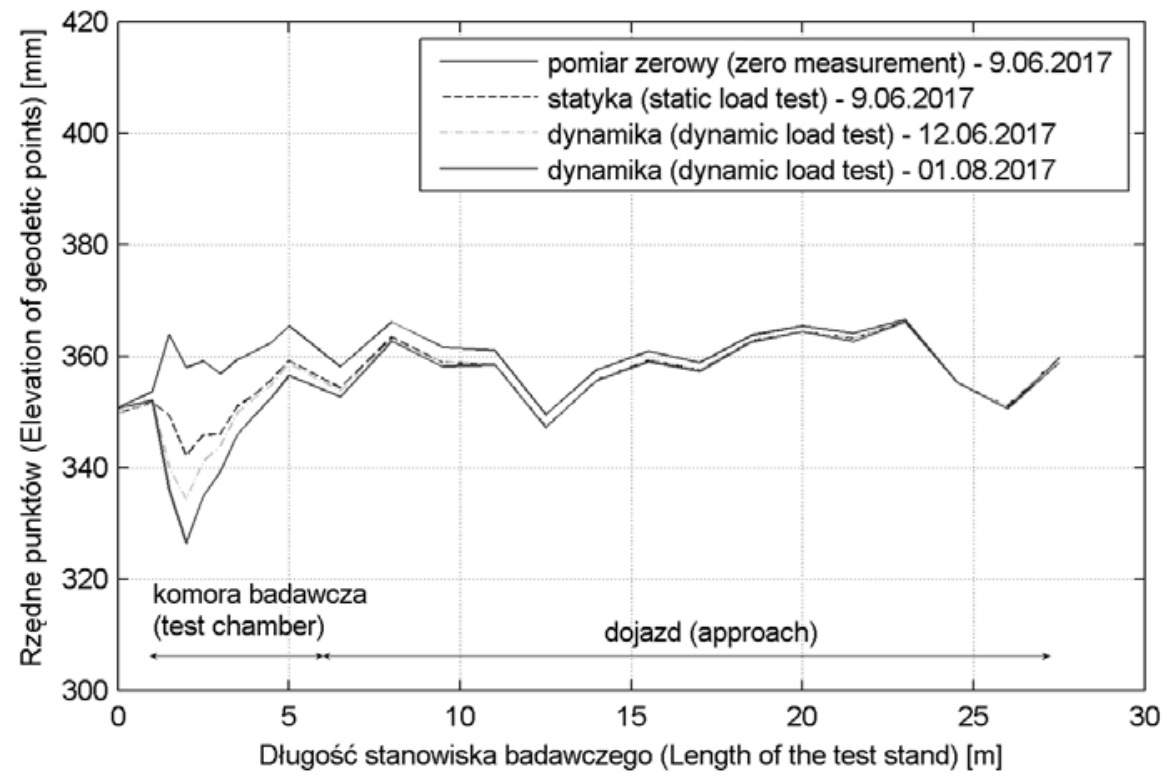

Rys. 15. Pomiary geodezyjne rzędnych konstrukcji nawierzchni stanowiska badawczego

Fig. 15. Geodetic measurements of elevation the pavement structure in test stand 
Ilościowa analiza porównawcza rozkładu parcia na przyczółek mostowy (w szczególności zintegrowany $\mathrm{z}$ przęsłem) przeprowadzona na podstawie wyników badań i analiz numerycznych pozwala stwierdzić, że występuje znacząca redukcja parcia dla zasypki z materiałów gumowych (pakiety SZOS, strzępy gumowe) w porównaniu do zasypki z piasku średniego:

- około 2-krotna różnica na poziomie 1,0 i $2,2 \mathrm{~m}$ poniżej poziomu terenu przy pionowym ustawieniu ściany (wychylenie $0 \mathrm{~mm}$ ),

- około 4-krotna różnica na poziomie 3,4 i 4,6 m poniżej poziomu terenu przy pionowym ustawieniu ściany,

- około 4-krotna różnica na poziomie 1,0 i 2,2 m poniżej poziomu terenu przy wychyleniu ściany o $15 \mathrm{~mm}$,

- około 8-krotna różnica na poziomie 3,4 i 4,6 m poniżej poziomu terenu przy wychyleniu ściany o $15 \mathrm{~mm}$.

Uwzględniając uzyskane wyniki badań i analiz, można stwierdzić, że:

- parcie na przyczółek generowane przez zasypkę z pakietów SZOS i warstwy buforowej ze strzępów gumowych ma charakter parcia silosowego,

- zasypkę z pakietów SZOS wypełniającą klin odłamu konstrukcji oporowej można traktować w obliczeniach jako samostateczny blok niegenerujący parcia.

\section{PIŚMIENNICTWO}

Duda, A. (2017a). Wybrane sposoby wykorzystania zużytych opon samochodowych w budownictwie komunikacyjnym. Journal of Civil Engineering, Environment and Architecture, 34(64), 381-396. doi: 10.7862/rb.2017.221

Duda, A. (2017b). Badania materiałowe drutów spinających pakiety sprasowanych zużytych opon samochodowych i ich połączeń. W J. Nyćkowiak i J. Leśny (red.), Badania i Rozwój Młodych Naukowców w Polsce (strony 15-22). Nauki techniczne i inżynieryjne. Część 9. Lublin: Wydawnictwo Młodzi Naukowcy.
Duda, A. (2017c). Badania metodą nieniszczącą naciągu drutów spinających pakiety sprasowanych zużytych opon samochodowych. W J. Nyćkowiak i J. Leśny (red.), Badania i Rozwój Młodych Naukowców w Polsce (strony 23-30). Nauki techniczne i inżynieryjne. Część 9. Lublin: Wydawnictwo Młodzi Naukowcy.

Duda, A. i Sobala, D. (2017a). Badania zużytych opon do wykorzystania w budownictwie (strony 74-77). Builder.

Duda, A. i Sobala, D. (2017b). Initial research on recycled tyre bales for road infrastructure applications. SSP - Journal of Civil Engineering - Selected Scientific Papers, 2(12), 55-62. doi: https://doi.org/10.1515/sspjce2017-0019

Duda, A., Sobala, D. i Siwowski, T. (2017). Badania wytrzymałości na ścinanie geokompozytów wykonanych z pakietów sprasowanych zużytych opon i materiału zasypowego. Acta Scientiarum Polonorum Architectura, 16(3), 3-12. doi: 10.22630/ASPA.2017.16.3.01

Duda, A., Sobala, D., Siwowski, T. i Kaleta, D. (2016). Wykorzystanie materiałów z recyklingu opon samochodowych w budownictwie komunikacyjnym. Archiwum Instytutu Inżynierii Ladowej, 21, 97-111.

Geosyntec Consultants, Inc. (2008). Guidance Manual for Engineering Uses of Scrap Tires. Maryland Environmental Service, Annapolis, Maryland, USA.

PAS 108:2007. Specification for the production of tyre bales for use in construction. British Standards Institution, London, UK.

PN-B-03020:1981. Grunty budowlane . Posadowienie bezpośrednie budowli. Obliczenia statyczne i projektowanie.

PN-EN 1991-1-5:2005/NA:2010. Eurokod 1: Oddziaływania na konstrukcje. Część 1-5: Oddziaływania ogólne. Oddziaływania termiczne.

PN-EN 1992-1-1:2008. Eurokod 2: Projektowanie konstrukcji z betonu. Część 1-1: Reguły ogólne i reguły dla budynków.

Sobala, D. (2002). Wptyw wybranych czynników meteorologicznych na odkształcenia przęset mostów stalowych: naturalne oddziatywania termiczne (rozprawa doktorska). Warszawa: Politechnika Warszawska.

Zornberg, J. G., Christopher, B. R. i Oosterbaan, M. D. (2005). Tire Bales in Highway Applications: Feasibility and Properties Evaluation. Colorado Department of Transportation, Report No. CDOT-DTD-R-2005-2, Denver, Colorado, USA. 


\section{RESEARCH ON THE RECYCLED TYRE BALES BACKFILL PRESSURE ON BRIDGE ABUTMENT}

\section{ABSTRACT}

This article describes the tests of the pressure distribution on bridge abutment generated by the backfill made of the recycled car tyres compressed in the form of bales with interfaces of medium sands and a buffer layer with tyre shreds. Backfill pressure distribution was measuring continuously over a period of three months using a pressure sensors. Static and dynamic load tests of abutment were conducted and cyclic horizontal displacements of the abutment wall, as a simulation of thermal elongation/shortening of the integral bridge span were also performed. The results of pressure field measurements were compared with results of numerical analysis performed using the GEO5 program basing on finite element method. Compatibility results of field measurements and numerical analysis was pretty good, and the maximum difference was about 25\%. Based on field measurements and numerical analysis, a 2-4 times reduction of pressure on bridge abutment was found, if the tyre bales had been used, compared to conventional backfilling of medium sand.

Key words: bridge abutment, backfill pressure, tyre bales, recycling 